\title{
Numerical Study of Heat and Mass Transfer during Cryopreservation Process with Application of Directed Interval Arithmetic
}

\author{
Alicja Piasecka-Belkhayat (D) and Anna Skorupa * (D) \\ Department of Computational Mechanics and Engineering, Silesian University of Technology, Konarskiego 18A, \\ 44-100 Gliwice, Poland; alicja.piasecka-belkhayat@polsl.pl \\ * Correspondence: anna.skorupa@polsl.pl
}

Citation: Piasecka-Belkhayat, A.;

Skorupa, A. Numerical Study of Heat and Mass Transfer during

Cryopreservation Process with Application of Directed Interval Arithmetic. Materials 2021, 14, 2966. https://doi.org/10.3390/ma14112966

Academic Editors: Paweł Fritzkowski, Tomasz Strek and Hubert Jopek

Received: 26 April 2021

Accepted: 26 May 2021

Published: 31 May 2021

Publisher's Note: MDPI stays neutral with regard to jurisdictional claims in published maps and institutional affiliations.

Copyright: (c) 2021 by the authors. Licensee MDPI, Basel, Switzerland. This article is an open access article distributed under the terms and conditions of the Creative Commons Attribution (CC BY) license (https:/ / creativecommons.org/licenses/by/ $4.0 /)$.
Abstract: In the present paper, numerical modelling of heat and mass transfer proceeding in a two-dimensional axially symmetrical articular cartilage sample subjected to a cryopreservation process is presented. In the model under consideration, interval parameters were assumed. The heat transfer process is described using the Fourier interval equation, while the cryoprotectant transport (DMSO) across the cell membrane is analyzed using a two-parameter model taking into account the simulation of the water volume in the chondrocytes and the change in DMSO concentration over time. The liquidus tracking (LT) protocol introduced by Pegg et al. was used to model the cryopreservation process. This procedure divides the heating and cooling phases into eight and seven steps, respectively, allowing precise regulation of temperature and cryoprotectant (CPA) concentration of bathing solutions. This protocol protects chondrocytes from ice crystal, osmotic stress, and electrolyte damage. The obtained interval concentrations of cryoprotectant in chondrocytes were compared with previous simulations obtained using the deterministic model and they are mostly in agreement with the simulation data.

Keywords: cryopreservation; heat transfer; mass transfer; interval finite difference method; directed interval arithmetic

\section{Introduction}

Cryopreservation is the storage of cells, tissues, or other biological structure at low temperatures without injuring them. This approach has many practical applications, including usage in medicine. The process is applied to preserve stem cells (tissue engineering research) or to cryobank transported organs (in transplantology) [1-3].

Cryopreservation can be accomplished via two methods, slow freezing and vitrification. These techniques differ principally in cooling rate and in cryoprotectant (CPA) concentration. The slow freezing method is carried out at a rate of approx. $-1{ }^{\circ} \mathrm{C} / \mathrm{min}$ with a low CPA concentration of about 1-2 M. This procedure has a low risk of tissue damage from osmotic shock to cells or the chemical toxic effects of CPA. The disadvantage is the possibility of tissue injury caused by ice crystal formation. On the other hand, vitrification is the conversion from a liquid to a vitreous phase at a cooling rate of approx. $-100{ }^{\circ} \mathrm{C} / \mathrm{min}$ to avoid the ice crystal formation. This method uses a high concentration of CPA (about 4-8 M), which increases the risk of tissue damage through CPA toxicity and the possibility of osmotic shock to cells [2,3].

However, cells such as chondrocytes in articular cartilage are susceptible to injury due to the forming of ice crystals, which makes cryopreservation using conventional methods difficult [4]. To solve this problem, Pegg et al. [5] and Wang et al. [6] used another procedure called the liquidus tracking (LT) method. This technique was devised by Farrant (1965) [7] and further advanced by Elford et al. (1972) [8]. This approach precisely regulates the temperature and the CPA concentration of bathing solutions. The temperatures in the 
sample are above or on the liquidus line (the melting point is changed by the CPA impact). This prevents ice crystallization and the exposition of the cryopreserved tissues to high concentrations of CPA at the same time [4].

An opportunity to further develop cryopreservation is to create appropriate mathematical and numerical models. A multi-physical field weak coupling problem mainly consists of modelling the following processes: heat transfer, including the crystallization and moving boundary problem, as well as mass transport at the macroscale in the extracellular matrix and at the microscale-through the cell membrane [2]. Cryopreservation by slow freezing [9] and by vitrification [10-12] can both be analyzed. These models are considered not only for articular cartilage [12-16] but also for other biological tissues or cells, such as stem cells $[9,17,18]$.

Modelling mass transfer across the cell membrane is used to estimate the CPA concentration in cells (chondrocytes for articular cartilage). The model currently applied is two-parameter (2-P) formalism [14,19-22], which is an extension of the Jacobs and Steward model $(1932)[23,24]$. They proposed two combined differential equations describing the transport of permeable solute and water [23,25]. Kedem and Katchalsky (1958) [26] prepared another solution to the mass transfer problem at the microscale, where the membrane permeability equation is related to three parameters [18,20,22,25,27]. In the articles [28-30], alternative models suggested by Mazur (1963) [31] and expanded by Levin et al. (1976) are presented [32].

The microscale mass transfer model should be supplemented by the following analyses: mass transport in the extracellular matrix and thermal processing in the tissue. The model of mass transport at the macroscale is based on Fick's second law, which provides for a concentration at a given time associated with diffusion [10,12-16,33]. The temperature distribution is determined from the Fourier equation $[9-11,13,14]$. In the modelling of thermal processes, the phase changes [34-36] or the crystallization [2,9-11] phenomena, as well as the moving boundary problem $[2,36,37]$, can be considered.

Mathematical models of cryopreservation in previous works determined the parameters of the equations as deterministic values. As a consequence, the thermal processes and mass processes can be inaccurately interpreted, because the phenomena that occur in biological structures are stochastic and random. It is not possible to carry out a simulation for all available defined experimental values of parameters, which depend on many circumstances (age, occupation, gender, etc.). Therefore, investigators have decided to establish average values of these factors and use a deterministic model. To avoid this simplification and, at the same time, omit time-consuming stochastic calculation, it is sensible to use interval arithmetic. Results obtained using the interval arithmetic rules are represented in the form of ranges that contain correct simulation results. This is essential in biomechanics because thermophysical parameters, such as thermal conductivity or volumetric specific heat, can vary to some extent $[38,39]$.

The paper presents the numerical analysis of the process of CPA transport across cell membrane during cryopreservation of articular cartilage samples. This model is weakly coupled to macroscale phenomena, such as heat and mass transfer, in the extracellular matrix. The LT protocol is used for the simulation. In the research, mass transport at the microscale is described by the interval 2-P formalism, which is complemented by results from the interval Fourier equation and the interval mass transfer equation based on the interval Fick's second law. In the model, some thermophysical parameters are introduced using interval arithmetic, and, as a result, uncertain values will be properly construed. The interval results are compared with simulations data from Yu et al. [13].

\section{Materials and Methods}

The presented model simulates the cryopreservation process using the LT protocol proposed by Pegg et al. [5]. During the experiment, a cylindrical ovine articular cartilage sample is immersed in CPTes2 bathing solution, which is a potassium-rich mixture. In the investigations, the chemical composition of the CPA solution is simplified to DMSO, $\mathrm{KCl}$, 
and $\mathrm{H}_{2} \mathrm{O}$. Additionally, temperature and concentration of the mixture were controlled by a computer system. The state of the bathing solution refers to the boundary conditions, which supplemented the mathematical and numerical models.

\section{Mathematical Model}

The change in water volume in the chondrocytes and the change in the intracellular CPA mole number over time is simulated using an interval two-parameter model $[13,14,40]$, which, for a cylindrical coordinate system, is of the form:

$$
\begin{gathered}
\frac{\mathrm{d} \bar{V}_{w}(r, z, t)}{\mathrm{d} t}=-\bar{L}_{p}(r, z, t) A R_{g} \bar{T}(r, z, t)\left(\bar{M}^{e}(r, z, t)-\bar{M}^{i}(r, z, t)\right), \\
\frac{\mathrm{d} \bar{N}_{d}(r, z, t)}{\mathrm{d} t}=\bar{P}_{s}(r, z, t) A\left(\bar{M}^{e}(r, z, t)-\bar{M}^{i}(r, z, t)\right),
\end{gathered}
$$

where $\bar{V}_{w}(r, z, t)$ is the interval water volume in the chondrocyte, $t$ is the time, $r$ and $z$ denote the cylindrical coordinates, $\bar{N}_{d}$ is the CPA mole number in the chondrocyte, $\bar{L}_{p}(r, z, t)$ is the interval hydraulic conductivity, $\bar{P}_{s}(r, z, t)$ is the interval permeability of CPA through the cell membrane, $A$ is the chondrocyte surface area, $R_{g}$ is the gas constant equal to $8.314 \mathrm{~J} \cdot \mathrm{mol}^{-1} \cdot \mathrm{K}^{-1}, \bar{T}(r, z, t)$ is the interval tissue temperature, and $\bar{M}(r, z, t)$ is the interval osmolarity, where the superscripts $e$ and $i$ refer to the extracellular and intracellular solutions, respectively.

The interval hydraulic conductivity, which determines the water permeability of a cell membrane, and the interval permeability of CPA across the cell membrane are described by the following equations [13]:

$$
\begin{aligned}
& \bar{L}_{p}(r, z, t)=A_{L p} \exp \left(\frac{E_{A, L p}}{R_{g} \bar{T}(r, z, t)}\right), \\
& \bar{P}_{S}(r, z, t)=A_{P_{S}} \exp \left(\frac{E_{A, P s}}{R_{g} \bar{T}(r, z, t)}\right),
\end{aligned}
$$

where $A_{L p}$ and $A_{P_{S}}$ are pre-exponential factors, and $E_{A, L p}$ and $E_{A, P_{S}}$ are activation energies for $\bar{L}_{p}$ and $\bar{P}_{s}$, respectively.

The osmolarity, which defines the number of moles of osmotically active substance in $1 \mathrm{~L}$ of solution, can be calculated on the basis of the osmolality of the solution. The osmolality is the number of moles of osmotically active substances dissolved in $1 \mathrm{~kg}$ of a solvent (e.g., water). For an undiluted solution of two solutes, the interval value of the osmolality can be expressed as $[13,25]$ :

$$
\begin{gathered}
\bar{\pi}^{f}(r, z, t)=k_{\text {diss }} \bar{m}_{k}^{f}(r, z, t)+\bar{m}_{d}^{f}(r, z, t)+B_{k}\left(k_{\text {diss }} \bar{m}_{k}^{f}(r, z, t)\right)^{2}+ \\
+B_{d}\left(\bar{m}_{d}^{f}(r, z, t)\right)^{2}+\left(B_{k}+B_{d}\right) k_{\text {diss }} \bar{m}_{k}^{f}(r, z, t) \bar{m}_{d}^{f}(r, z, t)
\end{gathered}
$$

where $\bar{\pi}^{f}$ is the interval osmolality, $k_{\text {diss }}$ is the dissociation constant, $\bar{m}^{f}$ is the interval molality, and $B$ is the second osmotic virial coefficient, where the subscripts $k$ and $d$ represent the $\mathrm{KCl}$ and the $\mathrm{CPA}$ (exactly DMSO), respectively. Let us denote that the superscript $f$ refers to the superscript $e$ or $i$ (extracellular or intracellular solution).

The molality of species $j$ (e.g., $k$ or $d$ ) is defined as the number of moles of the dissolved substance in $1 \mathrm{~kg}$ of solvent. When the interval mass fraction is known (the mass fraction is the ratio of the mass of a given component to the mass of the entire mixture), the interval molality can be determined:

$$
\bar{m}_{j}^{f}(r, z, t)=\frac{\bar{\omega}_{j}^{f}(r, z, t)}{\left(1-\bar{\omega}_{j}^{f}(r, z, t)\right) M_{a t . j}},
$$


where $\bar{\omega}_{j}^{f}$ is the interval mass fraction of species $j$ and $M_{a t . j}$ is the molar mass of the species $j$. The molar mass corresponds to the molecular mass:

$$
M_{a t . j} \approx M_{u, j} \cdot 1\left[\mathrm{~g} \cdot \mathrm{mol}^{-1}\right],
$$

where $M_{u, j}$ is the molecular mass of species $j$, which is given by the sum of the relative atomic mass of the elements.

The interval mass fraction can be calculated by the dependence [13]:

$$
\bar{\omega}_{j}^{f}(r, z, t)=\bar{C}_{j}^{f}(r, z, t) \frac{M_{a t . j}}{\rho_{j}}
$$

where $\bar{C}_{j}^{f}$ is the interval concentration of species $j$ and $\rho_{j}$ is the density of species $j$. It should be noted that concentration is also called molarity and is defined as the mole number per liter of the solution.

After defining the interval osmolality (see Equation (5)), the interval osmolarity can be determined [13]:

$$
\bar{M}^{f}(r, z, t)=\frac{\bar{\pi}^{f}(r, z, t) \bar{\omega}_{w}^{f}(r, z, t)}{\sum \bar{V}_{j}^{f}(r, z, t)},
$$

where $\bar{V}_{j}^{f}$ is the interval volume per unit of mass of species $j$. It should be noted that subscript $w$ represents $\mathrm{H}_{2} \mathrm{O}$.

The interval volume per unit mass is calculated [13]:

$$
\bar{V}_{j}^{f}(r, z, t)=\frac{\bar{\omega}_{j}^{f}(r, z, t)}{M_{a t . j}} v_{j},
$$

where $v_{j}$ is the partial molar volume of species $j$.

It is also important to know the interval extracellular and intracellular concentrations, which are described by the following interval equations [13-15,18,22,27,40,41]:

$$
\begin{gathered}
\frac{\partial \bar{C}_{d}^{e}(r, z, t)}{\partial t}=\left[\frac{1}{r} \frac{\partial}{\partial r}\left(\bar{D}_{d} r \frac{\partial \bar{C}_{d}^{e}(r, z, t)}{\partial r}\right)+\frac{\partial}{\partial z}\left(\bar{D}_{d} \frac{\partial \bar{C}_{d}^{e}(r, z, t)}{\partial z}\right)\right], \\
\bar{C}_{k}^{i}(r, z, t)=C_{k}^{e, 0}\left(\frac{V_{\text {cell }}^{0}-\bar{V}_{b}(r, z, t)-v_{d} N_{d}^{0}}{\bar{V}_{\text {cell }}(r, z, t)-\bar{V}_{b}(r, z, t)-v_{d} \bar{N}_{d}(r, z, t)}\right), \\
\bar{C}_{d}^{i}(r, z, t)=\frac{\bar{N}_{d}(r, z, t)}{\bar{V}_{\text {cell }}(r, z, t)-\bar{V}_{b}(r, z, t)-v_{d} \bar{N}_{d}(r, z, t)},
\end{gathered}
$$

where $\bar{D}_{d}$ is the interval diffusion coefficient, $V_{\text {cell }}^{0}$ is the cell volume (the superscript 0 represents the initial moment of simulation), $\bar{V}_{b}$ is the osmotically inactive volume of cells (for chondrocytes it is equal to $0.41 \bar{V}_{0}$ ), where $\bar{V}_{0}$ is the isotonic volume of cells. The interval normalized cell volume is defined:

$$
\frac{\bar{V}_{\text {cell }}}{V_{\text {cell }}^{0}}=\frac{\bar{V}_{d}+\bar{V}_{w}}{V_{\text {cell }}^{0}}=\frac{\bar{N}_{d} v_{d}+\bar{V}_{w}}{V_{\text {cell }}^{0}},
$$

The interval diffusion coefficient of CPA in extracellular matrix can be estimated by the Einstein-Stokes equation [41-43]:

$$
\bar{D}_{d}(r, z, t)=\frac{k_{B} \bar{T}(r, z, t)}{6 \pi \eta r_{s}}
$$


where $k_{B}$ is the Boltzmann constant, equal to $1.38 \times 10^{-23} \mathrm{~J} \cdot \mathrm{K}^{-1}, r_{s}$ is the radius of the spherical particle molecule, and $\eta$ is the dynamic viscosity.

The interval temperature coupled to the interval mass transfer model (compare with Equations (1), (2) and (15)) is determined using the interval Fourier equation [13,41]:

$$
\bar{c} \frac{\partial \bar{T}(r, z, t)}{\partial t}=\left[\frac{1}{r} \frac{\partial}{\partial r}\left(\bar{\lambda} r \frac{\partial \bar{T}(r, z, t)}{\partial r}\right)+\frac{\partial}{\partial z}\left(\bar{\lambda} \frac{\partial \bar{T}(r, z, t)}{\partial z}\right)\right]
$$

where $\bar{\lambda}$ is the interval thermal conductivity and $\bar{c}$ is the interval volumetric specific heat.

Equations (11)-(13) and (16) need to be supplemented with boundary conditions (see Figure 1) and initial conditions of the following form:

$$
t=0:\left\{\begin{array}{l}
\bar{T}(r, z, 0)=T^{0} \\
C_{d}^{e}(r, z, 0)=C_{d}^{e, 0} \\
C_{k}^{e}(r, z, 0)=C_{k}^{e, 0} \\
C_{k}^{i}(r, z, 0)=C_{d}^{i}(r, z, 0)=C^{i, 0}
\end{array},\right.
$$

where $T_{\text {bulk }}$ is the temperature of the bathing solution, $C_{\text {bulk }}$ is the CPA concentration in the bathing solution, $\alpha$ is the natural convection heat transfer coefficient, $T^{0}$ is the initial temperature and $C_{d}^{e, 0}$ the initial external DMSO concertation, $C_{k}^{e, 0}$ is the initial external $\mathrm{KCl}$ concentration, and $C^{i, 0}$ is the initial internal DMSO and $\mathrm{KCl}$ concentration [13].

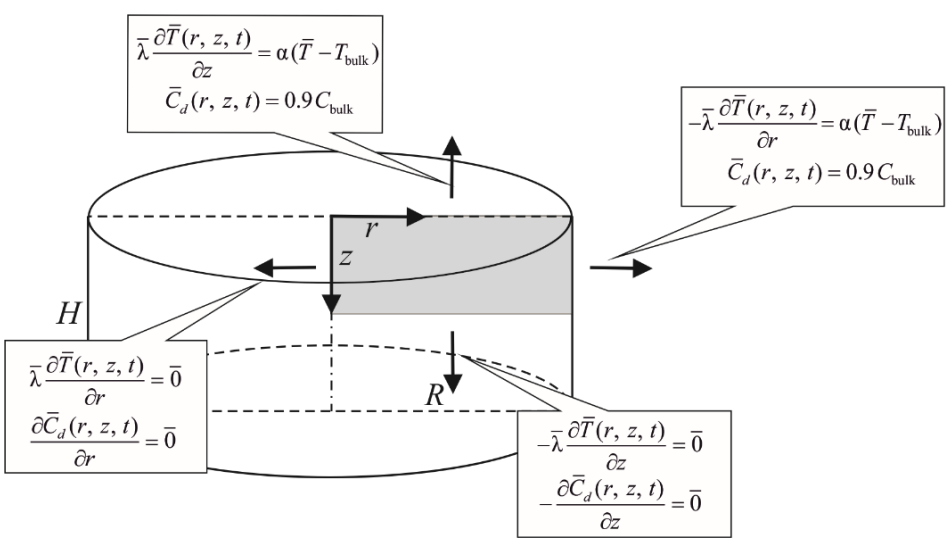

Figure 1. Domain considered and boundary conditions.

An axially symmetrical model of articular cartilage was considered, in particular the rectangle shown in Figure 1. Adiabatic boundary conditions were assumed on the symmetry axes (left and bottom sides), while on the other sides of the considered rectangle boundary conditions of 3rd type for temperature and 1st type for concentration were given.

The presented mathematical model does not include the phenomenon of phase changes. This is due to the fact that the liquidus tracking (LT) method is used to model heat and mass transfer. The LT protocol regulates the temperature and concentration in such a way that the temperature of the sample is above or on the liquidus line, which eliminates the probability of ice crystallization in cells-see the calculated eutectic temperatures and the melting points of tissue in [5].

\section{Numerical Algorithm}

Numerical model of thermal processes proceeding in domain of heating tissue is based on the finite difference method (FDM) in the version presented in [43,44].

A time grid with a constant step $\Delta t$ and a geometrical mesh are introduced at the beginning. The boundary nodes are located at the distance $0.5 h$ or $0.5 k$ with respect to the real boundary ( $h, k$ are the steps of regular mesh in directions $r$ and $z$ ), respectively 
(see Figure 2). This approach gives a better approximation of the Neumann and Robin boundary conditions $[38,41,43]$.

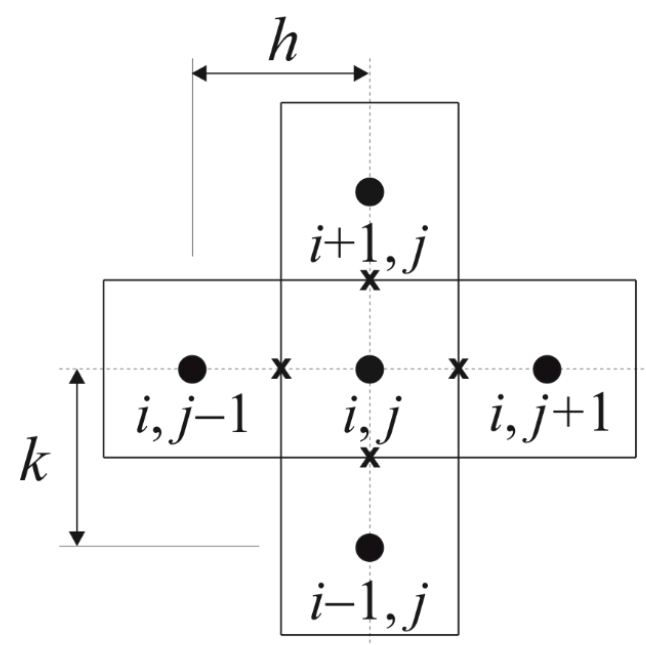

Figure 2. Five-point star.

The approximate form of the interval energy equation (Equation (16)) for the internal nodes $(i, j)$ and transition $t^{s-1} \rightarrow t^{s}$ is the following [41,43]:

$$
\begin{gathered}
\bar{c}_{i, j}^{s-1} \frac{\bar{T}_{i, j}^{s}-\bar{T}_{i, j}^{s-1}}{\Delta t}=\frac{\Phi_{i, j-1}}{\bar{R}_{i, j-1}^{s-1}}\left(\bar{T}_{i, j-1}^{s-1}-\bar{T}_{i, j}^{s-1}\right)+\frac{\Phi_{i, j+1}}{\bar{R}_{i, j+1}^{s-1}}\left(\bar{T}_{i, j+1}^{s-1}-\bar{T}_{i, j}^{s-1}\right)+, \\
\frac{\Phi_{i-1, j}}{\bar{R}_{i-1, j}^{s-1}}\left(\bar{T}_{i-1, j}^{s-1}-\bar{T}_{i, j}^{s-1}\right)+\frac{\Phi_{i+1, j}}{\bar{R}_{i+1, j}^{s-1}}\left(\bar{T}_{i+1, j}^{s-1}-\bar{T}_{i, j}^{s-1}\right)
\end{gathered},
$$

where

$$
\Phi_{i, j-1}=\frac{r_{i, j}-0.5 h}{r_{i, j} h}, \quad \Phi_{i, j+1}=\frac{r_{i, j}+0.5 h}{r_{i, j} h}, \quad \Phi_{i-1, j}=\Phi_{i+1, j}=\frac{1}{k},
$$

are the shape functions of differential mesh, while the thermal resistances are defined by the following formulas:

$$
\begin{aligned}
& \bar{R}_{i, j+1}^{s-1}=\frac{0.5 h}{\bar{\lambda}_{i, j}^{s-1}}+\frac{0.5 h}{\bar{\lambda}_{i, j+1}^{s-1}}, \quad \bar{R}_{i, j-1}^{s-1}=\frac{0.5 h}{\bar{\lambda}_{i, j}^{s-1}}+\frac{0.5 h}{\bar{\lambda}_{i, j-1}^{s-1}}, \\
& \bar{R}_{i+1, j}^{s-1}=\frac{0.5 k}{\bar{\lambda}_{i, j}^{s-1}}+\frac{0.5 k}{\bar{\lambda}_{i+1, j}^{s-1}}, \quad \bar{R}_{i-1, j}^{s-1}=\frac{0.5 k}{\bar{\lambda}_{i, j}^{s-1}}+\frac{0.5 k}{\bar{\lambda}_{i-1, j}^{s-1}},
\end{aligned}
$$

The interval mass diffusion equation (Equation (11)) is transformed in a similar way

$$
\begin{gathered}
\frac{\left(\bar{C}_{d}^{e}\right)_{i, j}^{s}-\left(\bar{C}_{d}^{e}\right)_{i, j}^{s-1}}{\Delta t}=\frac{\Phi_{i, j-1}}{\bar{W}_{i, j-1}^{s-1}}\left[\left(\bar{C}_{d}^{e}\right)_{i, j-1}^{s-1}-\left(\bar{C}_{d}^{e}\right)_{i, j}^{s-1}\right]+\frac{\Phi_{i, j+1}}{\bar{W}_{i, j+1}^{s-1}}\left[\left(\bar{C}_{d}^{e}\right)_{i, j+1}^{s-1}-\left(\bar{C}_{d}^{e}\right)_{i, j}^{s-1}\right], \\
+\frac{\Phi_{i-1, j}}{\bar{W}_{i-1, j}^{s-1}}\left[\left(\bar{C}_{d}^{e}\right)_{i-1, j}^{s-1}-\left(\bar{C}_{d}^{e}\right)_{i, j}^{s-1}\right]+\frac{\Phi_{i+1, j}}{\bar{W}_{i+1, j}^{s-1}}\left[\left(\bar{C}_{d}^{e}\right)_{i+1, j}^{s-1}-\left(\bar{C}_{d}^{e}\right)_{i, j}^{s-1}\right]
\end{gathered}
$$

where the diffusion resistances between the central node and the adjoining ones are the following:

$$
\begin{aligned}
& \bar{W}_{i, j+1}^{s-1}=\frac{0.5 h}{\left(\bar{D}_{d}\right)_{i, j}^{s-1}}+\frac{0.5 h}{\left(\bar{D}_{d}\right)_{i, j+1}^{s-1}}, \quad \bar{W}_{i, j-1}^{s-1}=\frac{0.5 h}{\left(\bar{D}_{d}\right)_{i, j}^{s-1}}+\frac{0.5 h}{\left(\bar{D}_{d}\right)_{i, j-1}^{s-1}}, \\
& \bar{W}_{i+1, j}^{s-1}=\frac{0.5 k}{\left(\bar{D}_{d}\right)_{i, j}^{s-1}}+\frac{0.5 k}{\left(\bar{D}_{d}\right)_{i+1, j}^{s-1}}, \quad \bar{W}_{i-1, j}^{s-1}=\frac{0.5 k}{\left(\bar{D}_{d}\right)_{i, j}^{s-1}}+\frac{0.5 k}{\left(\bar{D}_{d}\right)_{i-1, j}^{s-1}},
\end{aligned}
$$

Details of the above transformations are presented in [41]. 
The final form of the interval FDM equations (Equations (1) and (2)) of the twoparameter model for the internal nodes are

$$
\begin{gathered}
\bar{V}_{w i, j}^{s}=\bar{V}_{w i, j}^{s-1}+\Delta t\left[-\bar{L}_{p} A R_{g} \bar{T}\left(\bar{M}^{e}-\bar{M}^{i}\right)\right]_{i, j}^{s-1}, \\
N_{d i, j}^{s}=N_{d i, j}^{s-1}+\Delta t\left[\bar{P}_{s} A\left(\bar{M}^{e}-\bar{M}^{i}\right)\right]_{i, j}^{s-1},
\end{gathered}
$$

The systems of Equations (18), (22), (25), and (26) have been solved using the assumption of the stability condition for the explicit differential scheme [43,44].

All mathematical operations leading to the determination of the temperatures, extracellular and intracellular concentrations and other sought quantities require the application of directed arithmetic rules-more information can be found in [41].

\section{Results}

The simulation of CPA transport across a cell membrane for the homogenous cylindrical articular cartilage sample was carried out. The dimensions of the sample were as follows: $H=1 \mathrm{~mm}$ and $R=3 \mathrm{~mm}$. The thermophysical parameters of the tissue and the chemical properties of CPA, including DMSO, $\mathrm{KCl}$ and $\mathrm{H}_{2} \mathrm{O}$, are given in Table 1 . The chondrocytes' surface area and the chondrocytes' isotonic radius have been introduced, where $A=8.04 \times 10^{-10} \mathrm{~m}^{2}$ and $r_{\text {cell }}=8 \times 10^{-6} \mathrm{~m}$, which allows to calculate the isotonic volume of the cells $V_{0}=2.14 \times 10^{-15} \mathrm{~m}^{3}$. It is assumed that the initial cell volume is equal to the isotonic volume of the cells $V_{c e l l}^{0}=V_{0}$. Additionally, the following input data were used: initial temperature $T^{0}=22{ }^{\circ} \mathrm{C}$, initial external DMSO concentration $C_{d}^{e, 0}=0 \%$ $(w / w)$, initial external $\mathrm{KCl}$ concentration $C_{k}^{e, 0}=0.85 \%(w / w)$, initial internal DMSO and $\mathrm{KCl}$ concentrations $C^{i, 0}=0 \%(w / w)$, pre-expositional factors, such as $A_{L p}=9.1 \times 10^{-6} \mathrm{~m}^{2} \cdot \mathrm{s} \cdot \mathrm{kg}^{-1}$ and $A_{P S}=1.2 \times 10^{12} \mathrm{~m} \cdot \mathrm{s}^{-1}$ and the activation energy, $E_{A, L p}=45.73 \times 10^{3} \mathrm{~J} \mathrm{~mol}^{-1}$ and $E_{A, P_{s}}=107.40 \times 10^{3} \mathrm{~J} \mathrm{~mol}^{-1}[13,41]$.

\begin{tabular}{|c|c|c|c|c|}
\hline \multicolumn{5}{|c|}{ Thermophysical Tissue Parameters } \\
\hline \multicolumn{2}{|r|}{ Parameter } & \multicolumn{3}{|c|}{ Value } \\
\hline $\bar{\lambda}$ & $\left(\mathrm{W} \cdot \mathrm{m}^{-1} \cdot \mathrm{K}^{-1}\right)$ & \multicolumn{3}{|c|}{$\bar{\lambda}=[\lambda-0.05 \lambda, \lambda+0.05 \lambda]$, where $\lambda=0.518$} \\
\hline $\bar{c}$ & $\left(\mathrm{~J} \cdot \mathrm{m}^{-3} \cdot \mathrm{K}^{-1}\right)$ & \multicolumn{3}{|c|}{$\bar{c}=[c-0.05 c, c+0.05 c]$, where $c=3.924 \times 10^{6}$} \\
\hline$\alpha$ & $\left(\mathrm{W} \cdot \mathrm{m}^{-2} \cdot \mathrm{K}^{-1}\right)$ & \multicolumn{3}{|c|}{525} \\
\hline \multicolumn{5}{|c|}{ CPA Chemical Properties } \\
\hline \multirow{2}{*}{\multicolumn{2}{|c|}{ Parameter }} & \multicolumn{3}{|c|}{ Values } \\
\hline & & DMSO & $\mathrm{KCl}$ & $\mathrm{H}_{2} \mathrm{O}$ \\
\hline$r_{s}$ & $(\mathrm{~m})$ & $2.541 \times 10^{-10}$ & - & - \\
\hline$\eta$ & $(\mathrm{Pa} \cdot \mathrm{s})$ & $1.996 \times 10^{-3}$ & - & - \\
\hline$\rho$ & $\left(\mathrm{kg} \cdot \mathrm{m}^{-3}\right)$ & $1.1 \times 10^{3}$ & $1.98 \times 10^{3}$ & 997 \\
\hline$M_{a t .}$ & $\left(\mathrm{kg} \cdot \mathrm{mol}^{-1}\right)$ & $78.13 \times 10^{-3}$ & $74.5513 \times 10^{-3}$ & $18.015 \times 10^{-3}$ \\
\hline$B$ & $\left(\mathrm{~kg} \cdot \mathrm{mol}^{-1}\right)$ & 0.108 & 0 & - \\
\hline$v$ & $\left(\mathrm{~L} \cdot \mathrm{mol}^{-1}\right)$ & $70.97 \times 10^{-3}$ & $37.5 \times 10^{-3}$ & $18.07 \times 10^{-3}$ \\
\hline$k_{\text {diss }}$ & - & - & 1.772 & - \\
\hline
\end{tabular}

Table 1. Thermophysical parameters of the tissue and chemical properties of the CPA $[13,41,45]$.

The process was simulated using the interval finite difference method. The time step and the mesh steps were assumed as $\Delta t=0.001 \mathrm{~s}, h=0.0001 \mathrm{~m}$ and $k=0.00005 \mathrm{~m}$.

During modelling of the cryopreservation process, the LT protocol introduced by Pegg et al. in [5] was used. The procedure includes 8 steps in a cooling phase and 7 steps in a heating phase. During each step, the temperature and concentration of the bathing solution were controlled by computer. This ensured that no ice crystals were formed and 
that no cells were damaged by toxicity. It is worth mentioning that the impact of CPA causes a change in the melting point, and then the temperature of the cryopreserved sample was close to the liquidus track. Table 2 and Figure 3 present the assumption of the LT approach. The given values of the temperature and concentration of the bathing solution corresponded to the boundary conditions of the mathematical model.

Table 2. The assumption of the LT protocol $[5,13]$.

\begin{tabular}{|c|c|c|c|c|}
\hline \multirow[t]{2}{*}{ Phase } & \multirow[t]{2}{*}{ Step } & Time & $\begin{array}{c}\text { Temperature of } \\
\text { Bathing Solution }\end{array}$ & $\begin{array}{l}\text { Concentration of } \\
\text { Bathing Solution }\end{array}$ \\
\hline & & $t(\min )$ & $T_{\text {bulk }}\left({ }^{\circ} \mathrm{C}\right)$ & $C_{\text {bulk }}(\%(w / w))$ \\
\hline \multirow{8}{*}{ Cooling } & 1 & 10 & 22 & 10 \\
\hline & 2 & 10 & 22 & 20 \\
\hline & 3 & 30 & -5 & 29 \\
\hline & 4 & 30 & -8.5 & 38 \\
\hline & 5 & 30 & -16 & 47 \\
\hline & 6 & 30 & -23 & 56 \\
\hline & 7 & 30 & -35 & 63 \\
\hline & 8 & 30 & -48.5 & 72 \\
\hline \multirow{7}{*}{ Heating } & 1 & 30 & -48.5 & 63 \\
\hline & 2 & 30 & -35 & 56 \\
\hline & 3 & 30 & -23 & 47 \\
\hline & 4 & 30 & -16 & 38 \\
\hline & 5 & 30 & -8.5 & 29 \\
\hline & 6 & 30 & -5 & 20 \\
\hline & 7 & 45 & 22 & 0 \\
\hline
\end{tabular}




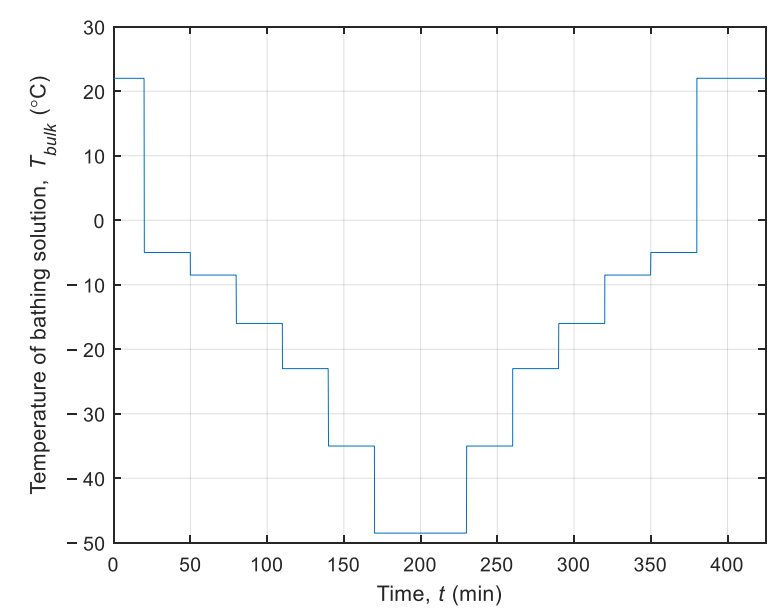

(a)

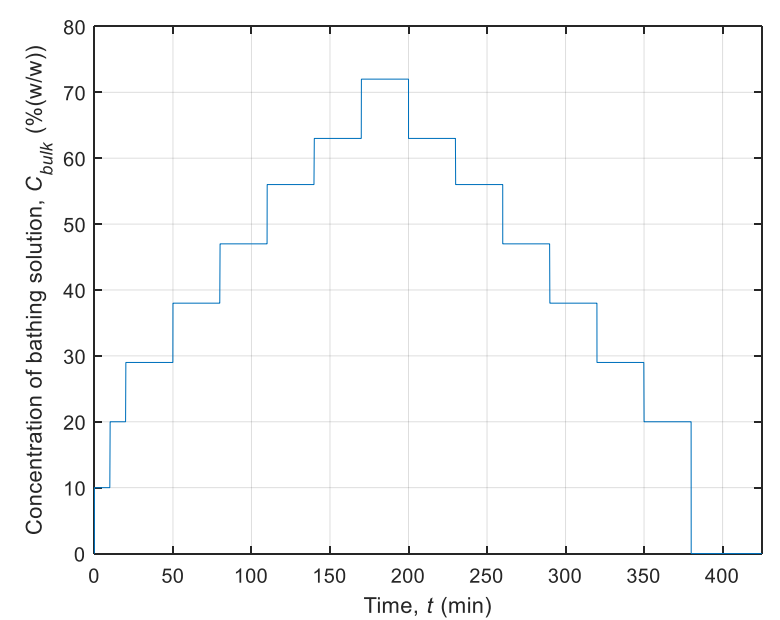

(b)

Figure 3. History of (a) the temperature and (b) the concentration of the bathing solution.

Firstly, simulation of the CPA concentration in the intracellular membrane using directed interval arithmetic was executed. Figure 4 illustrates the distribution of the concentration in chondrocytes located at the point with the coordinates $r=0.1 \mathrm{~mm}$ and $z=0.45 \mathrm{~mm}$. This refers to the first $20 \mathrm{~s}$ in step 3 of the cooling phase (Figure $4 \mathrm{a}$ ) and step 7 of heating phase (Figure $4 \mathrm{~b}$ ). It should be pointed out that, for each node of the domain considered, there are two curves representing the beginning and end of concentration intervals. The upper limit of the concentration interval is marked with a red line and the lower limit with a blue line. Figure 5 represents the CPA concentration in the entire analyzed area after $10 \mathrm{~s}$ in step 3 in the cooling phase.

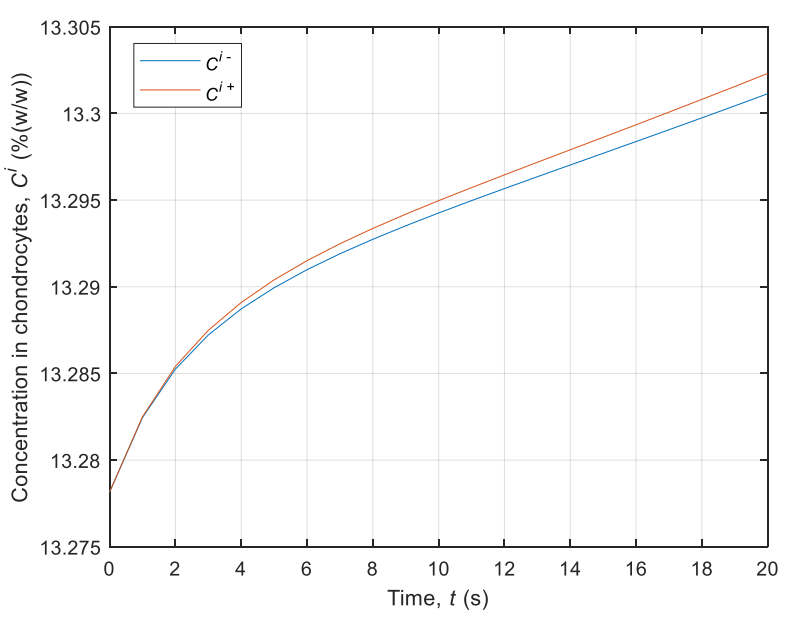

(a)

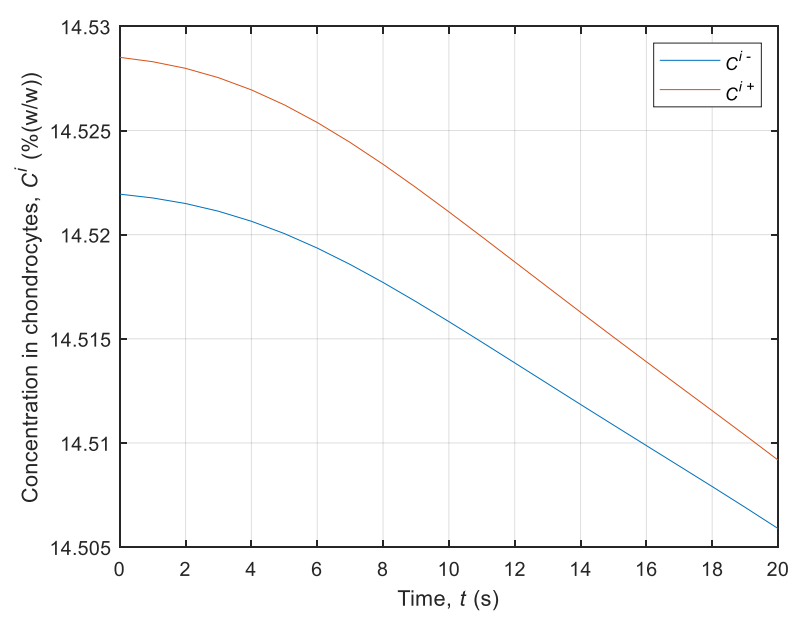

(b)

Figure 4. History of the intracellular concentration over time: (a) from $22{ }^{\circ} \mathrm{C}$ to $-5{ }^{\circ} \mathrm{C}$; (b) from $-5{ }^{\circ} \mathrm{C}$ to $22{ }^{\circ} \mathrm{C}$.

Afterwards, to better understand the phenomena occurring in chondrocytes, the simulation of CPA and water volume changing in the cell was performed without using interval arithmetic. In this model, the thermophysical parameters were defined as deterministic values (see deterministic values of $\lambda$ and $c$ in Table 1). Figure 6 shows a diagram of the number of moles of CPA over time during the whole process. Figure 7 presents changes in the intracellular water volume during cryopreservation. This diagram expresses the phenomenon of dehydration, which consists of water transport from the inside cell to the extracellular matrix. 


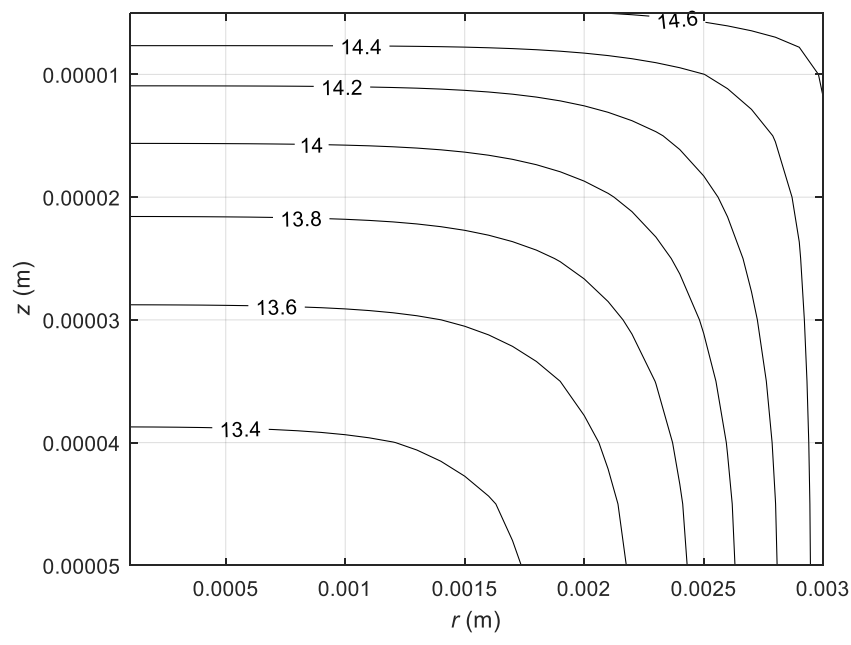

(a)

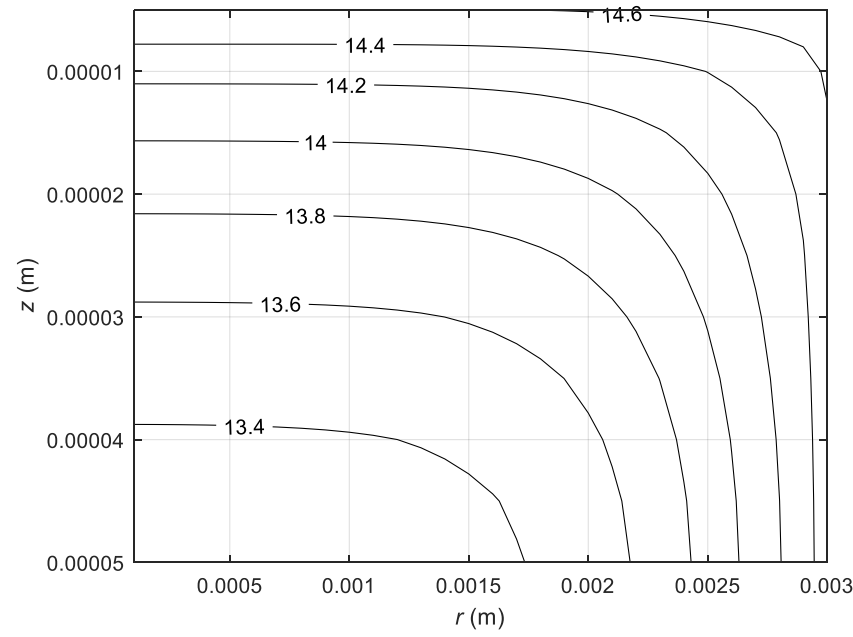

(b)

Figure 5. Distribution of the intracellular concentration after $10 \mathrm{~s}$ for transition from $22{ }^{\circ} \mathrm{C}$ to $-5{ }^{\circ} \mathrm{C}$ for: (a) $C_{d}^{i-} ;(\mathbf{b}) C_{d}^{i+}$.

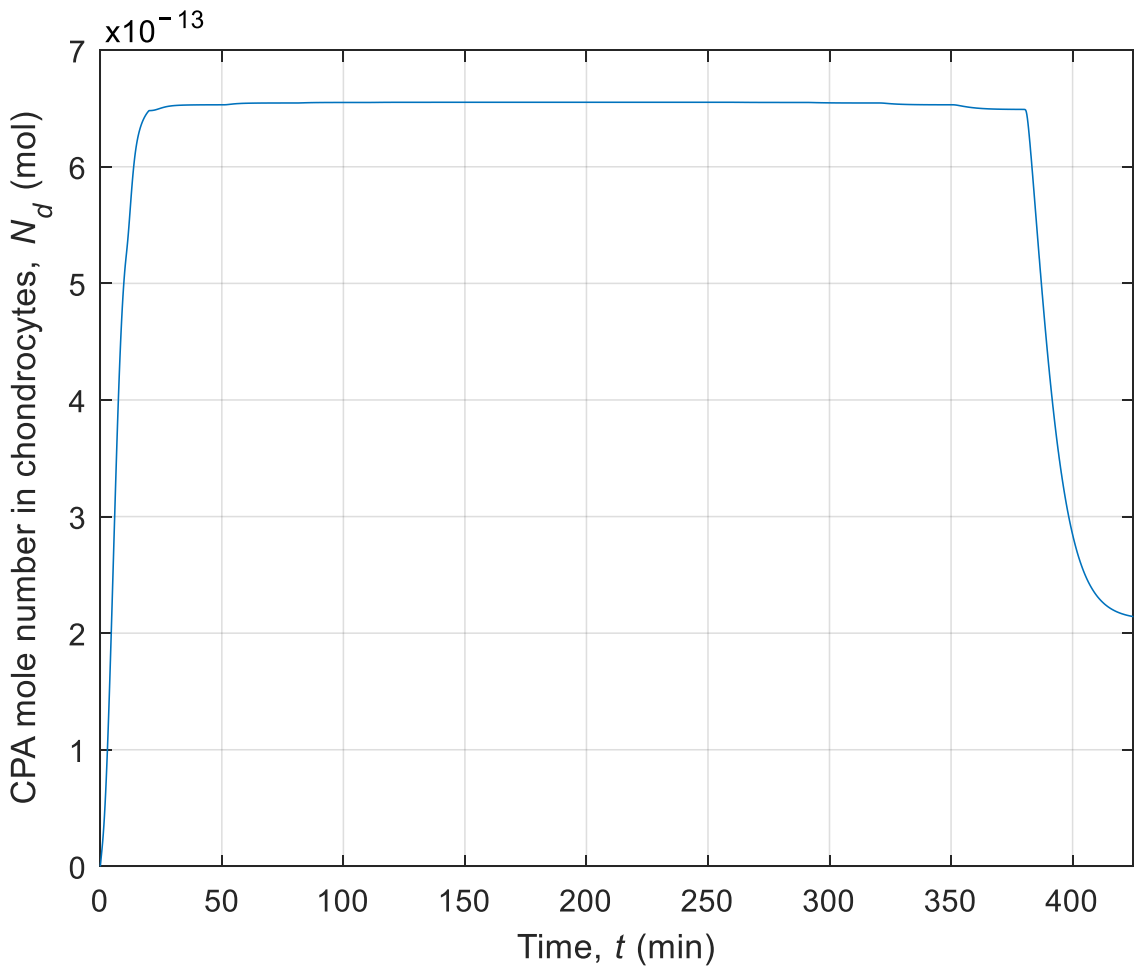

Figure 6. History of CPA mole number in chondrocytes during cryopreservation.

Then, the intracellular volume of water and CPA was also analyzed using interval arithmetic rules. Figure 8 demonstrates the CPA moles' number in the cell for the first $20 \mathrm{~s}$ in step 3 of the cooling phase and step 7 of the heating phase. These diagrams correspond to the intracellular CPA concertation (compare with Figure 4). Figure 9 shows a diagram of water volume over time for transition from $22{ }^{\circ} \mathrm{C}$ to $-5^{\circ} \mathrm{C}$. It should be noted that the obtained intervals are narrow. 


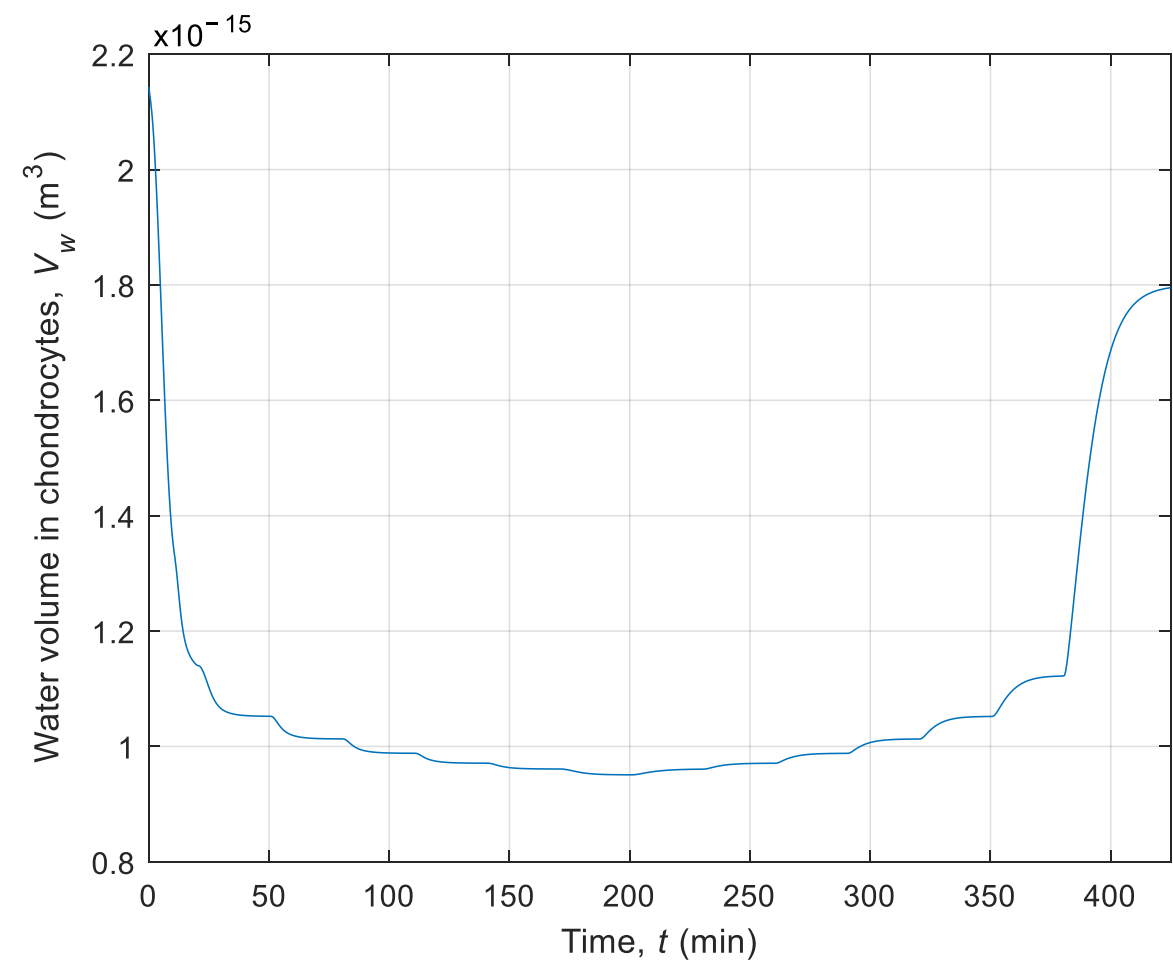

Figure 7. History of water volume in chondrocytes during cryopreservation.

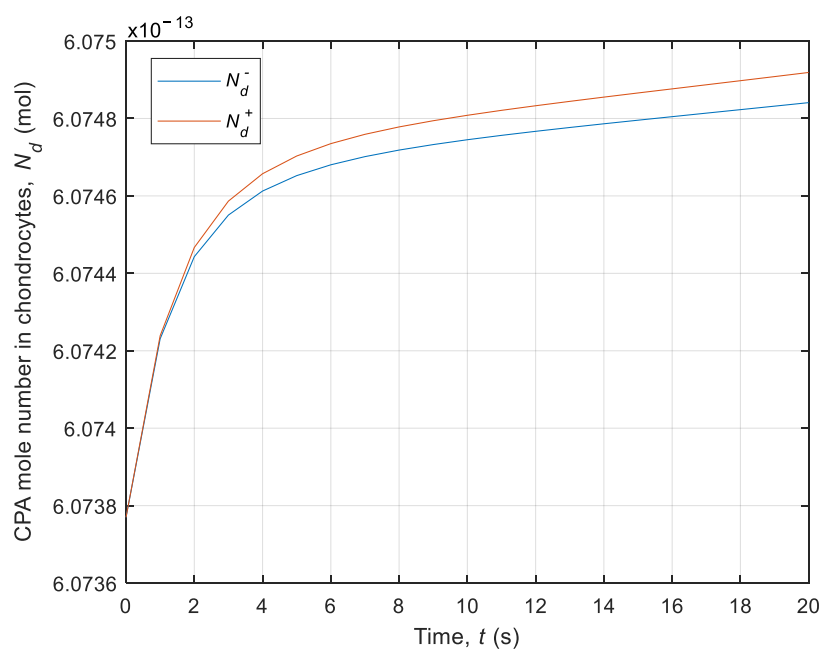

(a)

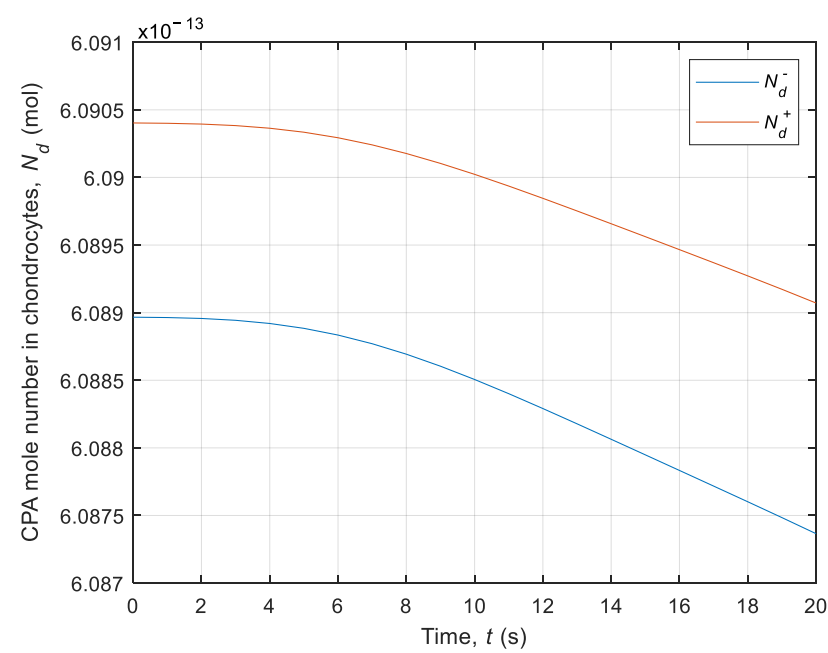

(b)

Figure 8. History of the intracellular CPA moles number over time: (a) from $22{ }^{\circ} \mathrm{C}$ to $-5{ }^{\circ} \mathrm{C}$; (b) from $-5{ }^{\circ} \mathrm{C}$ to $22{ }^{\circ} \mathrm{C}$. 


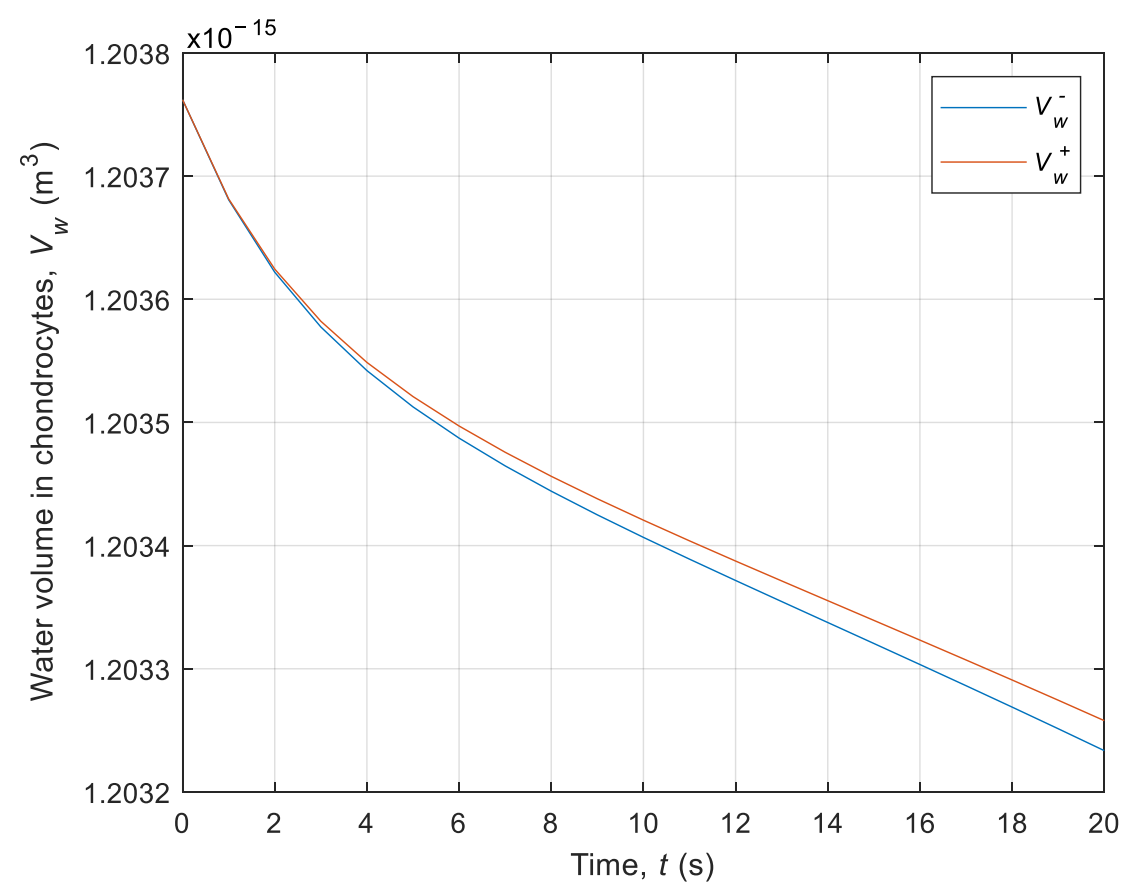

Figure 9. History of the intracellular water volume over time for transition from $22{ }^{\circ} \mathrm{C}$ to $-5{ }^{\circ} \mathrm{C}$.

Table 3 includes the values of intracellular quantities at the end of the given steps. The exact results of the extracellular temperature and CPA concentration can be found in previous work [41]. The obtained interval concentrations were also compared with the simulation data received by Yu et al. [13]. In individual steps, these values are close to each other. Significant discrepancies occur for steps where the temperature is low.

Table 3. Values of intracellular quantities at the end of each step.

\begin{tabular}{|c|c|c|c|c|c|c|c|c|c|c|}
\hline \multirow{2}{*}{ Phase } & \multirow{2}{*}{ Step } & \multicolumn{2}{|c|}{ CPA Concentration } & \multirow{2}{*}{$\begin{array}{c}\text { Yu et al.'s } \\
\text { Simulation Data } \\
\text { [13] } \\
C_{d}(\%(w / w))\end{array}$} & \multicolumn{2}{|c|}{ CPA Volume } & \multicolumn{2}{|c|}{ CPA Moles Number } & \multicolumn{2}{|c|}{ Water Volume } \\
\hline & & $C_{d}^{i-}(\%(w w))$ & $C_{d}^{i+}(\%(w w))$ & & $V_{d}{ }^{-}\left(\mathrm{m}^{3}\right) \times 10^{-17}$ & $V_{d}^{+}\left(\mathrm{m}^{3}\right) \times 10^{-17}$ & $N_{d}^{-}(\mathrm{mol}) \times 10^{-13}$ & $N_{d}{ }^{+}(\mathrm{mol}) \times 10^{-13}$ & $V_{w}{ }^{-}\left(\mathbf{m}^{3}\right) \times 10^{-16}$ & $V_{w}{ }^{+}\left(\mathrm{m}^{3}\right) \times 10^{-16}$ \\
\hline \multirow{8}{*}{ Cooling } & 1 & 4.330 & 4.330 & 6.70 & 2.816 & 2.816 & 3.967 & 3.967 & 15.297 & 15.297 \\
\hline & 2 & 13.278 & 13.278 & 15.68 & 4.311 & 4.311 & 6.074 & 6.074 & 12.038 & 12.038 \\
\hline & 3 & 21.513 & 21.520 & 24.42 & 4.358 & 4.362 & 6.140 & 6.147 & 10.816 & 10.818 \\
\hline & 4 & 29.172 & 29.182 & 31.86 & 4.371 & 4.379 & 6.160 & 6.170 & 10.288 & 10.290 \\
\hline & 5 & 37.371 & 37.385 & 38.33 & 4.375 & 4.383 & 6.164 & 6.176 & 9.960 & 9.962 \\
\hline & 6 & 46.059 & 46.076 & 44.02 & 4.376 & 4.385 & 6.166 & 6.179 & 9.740 & 9.741 \\
\hline & 7 & 53.079 & 53.107 & 47.26 & 4.376 & 4.385 & 6.166 & 6.179 & 9.614 & 9.615 \\
\hline & 8 & 62.071 & 62.338 & 48.63 & 4.376 & 4.385 & 6.166 & 6.179 & 9.494 & 9.493 \\
\hline \multirow{7}{*}{ Heating } & 1 & 53.272 & 53.921 & 50.32 & 4.376 & 4.385 & 6.166 & 6.179 & 9.600 & 9.613 \\
\hline & 2 & 46.155 & 46.185 & 50.72 & 4.376 & 4.385 & 6.166 & 6.179 & 9.737 & 9.740 \\
\hline & 3 & 37.452 & 37.453 & 44.99 & 4.375 & 4.383 & 6.164 & 6.176 & 9.958 & 9.960 \\
\hline & 4 & 29.238 & 29.236 & 36.27 & 4.371 & 4.379 & 6.160 & 6.170 & 10.285 & 10.287 \\
\hline & 5 & 21.575 & 21.573 & 27.05 & 4.358 & 4.363 & 6.140 & 6.147 & 10.810 & 10.812 \\
\hline & 6 & 14.522 & 14.529 & 18.86 & 4.321 & 4.3212 & 6.089 & 6.090 & 11.765 & 11.768 \\
\hline & 7 & 0.033 & 0.033 & 0.03 & 0.040 & 0.041 & 0.057 & 0.058 & 21.100 & 21.103 \\
\hline
\end{tabular}

\section{Discussion}

In the present study, numerical analysis of heat and mass transfer occurring in axially symmetrical articular cartilage sample subjected to the cryopreservation process is presented. The mathematical model is based on heat and mass diffusion interval equations, in conjunction with a model of transmembrane transport of CPA. A two-parameter model was used to analyze the transport of CPA (solution of DMSO, $\mathrm{KCl}$ and water) across the cell membrane, considering the simulated volume of water in chondrocytes and the change in the cryoprotectant concentration over time. Interval values of volume specific heat and thermal conductivity of articular cartilage were assumed for the modelled process. The interval FDM was used to solve the problem, applying the rules of directed interval arithmetic.

Since thermophysical parameters are often determined experimentally, as well as the phenomena that biological structures are unpredictable, it is reasonable to include in the 
mathematical model imprecise values instead of deterministic values. The application of the stochastic and randomized model is time-consuming and complicated, therefore applying interval arithmetic rules is proposed in the research. Using interval values, solutions in the form of intervals were obtained, which better reflect the analyzed process.

In the paper, the history of the intracellular concentration, the history of the intracellular water volume in the chondrocytes and the history of the intracellular CPA moles number in the cell have been presented. The results depict the phenomena that occur in cells during the process, such as dehydration. It can be also seen that, for low temperatures, wider intervals were obtained, while for positive temperatures the intervals were narrow. The obtained interval concentrations were compared with simulation data calculated using a deterministic model [13]. The interval results mostly coincide with Yu et al.'s simulation data. Slight differences are observed in those process steps in which the concentration is high (e.g., step 8 in the cooling phase or step 1 in the heating phase). The comparison of the deterministic model with the interval model allows us to conclude that the model modified by interval arithmetic is justified because the results are compatible, and the received ranges include the correct results, whereas the computation time is only slightly extended.

In a further stage of the study, the macroscale mass transfer equation will be supplemented with a velocity vector determined from the Navier-Stokes equation.

Author Contributions: Conceptualization, A.S. and A.P.-B.; methodology, A.S. and A.P.-B.; software, A.S.; validation, A.S. and A.P.-B.; formal analysis, A.S. and A.P.-B.; investigation, A.S.; resources, A.S. and A.P.-B.; data curation, A.S. and A.P.-B.; writing—original draft preparation, A.S.; writing—review and editing, A.P.-B.; visualization, A.S.; supervision, A.P.-B.; project administration, A.S.; funding acquisition, A.S. All authors have read and agreed to the published version of the manuscript.

Funding: The research was partially funded from financial resources from the statutory subsidy of the Faculty of Mechanical Engineering, Silesian University of Technology, in 2021.

Institutional Review Board Statement: Not applicable.

Informed Consent Statement: Not applicable.

Data Availability Statement: Data sharing not applicable.

Acknowledgments: The research was partially funded from financial resources from the statutory subsidy of the Faculty of Mechanical Engineering, Silesian University of Technology, in 2021.

Conflicts of Interest: The authors declare no conflict of interest.

\section{References}

1. Zhao, G.; Fu, J. Microfluidics for cryopreservation. Biotechnol. Adv. 2017, 35, 323-336. [CrossRef] [PubMed]

2. Xu, F.; Moon, S.; Zhang, X.; Shao, L.; Song, Y.S.; Demirci, U. Multi-scale heat and mass transfer modelling of cell and tissue cryopreservation. Philos. Trans. R. Soc. A Math. Phys. Eng. Sci. 2010, 368, 561-583. [CrossRef] [PubMed]

3. Jang, T.H.; Park, S.C.; Yang, J.H.; Kim, J.Y.; Seok, J.H.; Park, U.S.; Choi, C.W.; Lee, S.R.; Han, J. Cryopreservation and its clinical applications. Integr. Med. Res. 2017, 6, 12-18. [CrossRef]

4. Kay, A.G.; Hoyland, J.A.; Rooney, P.; Kearney, J.N.; Pegg, D.E. A liquidus tracking approach to the cryopreservation of human cartilage allografts. Cryobiology 2015, 71, 77-84. [CrossRef] [PubMed]

5. Pegg, D.E.; Wang, L.; Vaughan, D. Cryopreservation of articular cartilage. Part 3: The liquidus-tracking method. Cryobiology 2006, 52, 360-368. [CrossRef]

6. Wang, L.; Pegg, D.E.; Lorrison, J.; Vaughan, D.; Rooney, P. Further work on the cryopreservation of articular cartilage with particular reference to the liquidus tracking (LT) method. Cryobiology 2007, 55, 138-147. [CrossRef]

7. Farrant, J. Mechanism of Cell Damage During Freezing and Thawing and its Prevention. Nature 1965, 205, 1284-1287. [CrossRef]

8. Elford, B.C.; Walter, C.A. Effects of electrolyte composition and $\mathrm{pH}$ on the structure and function of smooth muscle cooled to -79 ${ }^{\circ} \mathrm{C}$ in unfrozen media. Cryobiology 1972, 9, 82-100. [CrossRef]

9. Hayashi, Y.; Horiguchi, I.; Kino-oka, M.; Sugiyama, H. Slow freezing process design for human induced pluripotent stem cells by modeling intracontainer variation. Comput. Chem. Eng. 2020, 132, 106597. [CrossRef]

10. Shi, M.; Feng, S.; Zhang, X.; Ji, C.; Xu, F.; Lu, T.J. Droplet based vitrification for cell aggregates: Numerical analysis. J. Mech. Behav. Biomed. Mater. 2018, 82, 383-393. [CrossRef] 
11. Zhang, Y.; Zhao, G.; Chapal Hossain, S.M.; He, X. Modeling and experimental studies of enhanced cooling by medical gauze for cell cryopreservation by vitrification. Int. J. Heat Mass Transf. 2017, 114, 1-7. [CrossRef] [PubMed]

12. Shardt, N.; Al-Abbasi, K.K.; Yu, H.; Jomha, N.M.; McGann, L.E.; Elliott, J.A.W. Cryoprotectant kinetic analysis of a human articular cartilage vitrification protocol. Cryobiology 2016, 73, 80-92. [CrossRef] [PubMed]

13. Yu, X.; Zhang, S.; Chen, G. Modeling the addition/removal of dimethyl sulfoxide into/from articular cartilage treated with the liquidus-tracking method. Int. J. Heat Mass Transf. 2019, 141, 719-730. [CrossRef]

14. Lawson, A.; Mukherjee, I.N.; Sambanis, A. Mathematical modeling of cryoprotectant addition and removal for the cryopreservation of engineered or natural tissues. Cryobiology 2012, 64, 1-11. [CrossRef]

15. Zhang, S.Z.; Yu, X.Y.; Chen, G.M. Permeation of dimethyl sulfoxide into articular cartilage at subzero temperatures. J. Zhejiang Univ. Sci. B 2012, 13, 213-220. [CrossRef]

16. Mukherjee, I.N.; Li, Y.; Song, Y.C.; Long, R.C.; Sambanis, A. Cryoprotectant transport through articular cartilage for long-term storage: Experimental and modeling studies. Osteoarthr. Cartil. 2008, 16, 1379-1386. [CrossRef]

17. Casula, E.; Traversari, G.; Fadda, S.; Klymenko, O.V.; Kontoravdi, C.; Cincotti, A. Modelling the osmotic behaviour of human mesenchymal stem cells. Biochem. Eng. J. 2019, 151,1-13. [CrossRef]

18. Xu, Y.; Zhang, L.; Xu, J.; Wei, Y.; Xu, X. Membrane permeability of the human pluripotent stem cells to Me 2SO, glycerol and 1,2-propanediol. Arch. Biochem. Biophys. 2014, 550-551, 67-76. [CrossRef]

19. Zhou, X.; Jiang, Z.; Liang, X.M.; Liu, J.; Fang, P.; Liu, Z.; Gao, D. Microfiltration-based sequential perfusion: A new approach for improved loading/unloading of cryoprotectants. Sens. Actuators B Chem. 2020, 312, 127957. [CrossRef]

20. Zhou, X.; Liang, X.M.; Wang, J.; Du, P.; Gao, D. Theoretical and experimental study of a membrane-based microfluidics for loading and unloading of cryoprotective agents. Int. J. Heat Mass Transf. 2018, 127, 637-644. [CrossRef]

21. Zheng, Y.; Zhao, G.; Zhang, Y.; Gao, R. On-chip loading and unloading of cryoprotectants facilitate cell cryopreservation by rapid freezing. Sens. Actuators B Chem. 2018, 225, 647-656. [CrossRef]

22. Xu, X.; Cui, Z.; Urban, J.P. Measurement of the chondrocyte membrane permeability to Me2SO, glycerol and 1,2-propanediol. Med. Eng. Phys. 2003, 25, 573-579. [CrossRef]

23. Jacobs, M.H.; Stewart, D.R. A simple method for the quantitative measurement of cell permeability. J. Cell. Comp. Physiol. 1932, 1, 71-82. [CrossRef]

24. Jacobs, M.H. The Simultaneous Measurement of Cell Permeability to Water and to Dissolved Substances. Am. J. Med. Sci. 1933, 185, 599. [CrossRef]

25. Elmoazzen, H.Y.; Elliott, J.A.W.; McGann, L.E. Osmotic Transport across Cell Membranes in Nondilute Solutions: A New Nondilute Solute Transport Equation. Biophys. J. 2009, 96, 2559-2571. [CrossRef] [PubMed]

26. Kedem, O.; Katchalsky, A. Thermodynamic analysis of the permeability of biological membranes to non-electrolytes. Biochim. Biophys. Acta 1958, 27, 229-246. [CrossRef]

27. Xu, X.; Cui, Z.F.; Wilkins, R.J.; Urban, J.P.G. Intracellular $\mathrm{pH}$ changes in isolated bovine articular chondrocytes during the loading and removal of cryoprotective agents. Cryobiology 2003, 46, 161-173. [CrossRef]

28. Devismita, D.; Kumar, A. Effect of cryoprotectant on optimal cooling rate during cryopreservation. Cryobiology 2015, 70, 53-59. [CrossRef]

29. Thirumala, S.; Gimble, J.M.; Devireddy, R.V. Transport phenomena during freezing of adipose tissue derived adult stem cells. Biotechnol. Bioeng. 2005, 92, 372-383. [CrossRef]

30. Wu, W.T.; Lyu, S.-R.; Hsieh, W.H. Cryopreservation and biophysical properties of articular cartilage chondrocytes. Cryobiology 2005, 51, 330-338. [CrossRef]

31. Mazur, P. Kinetics of water loss from cells at subzero temperatures and the likelihood of intracellular freezing. J. Gen. Physiol. 1963, 47, 347-369. [CrossRef] [PubMed]

32. Levin, R.L.; Cravalho, E.G.; Huggins, C.E. A membrane model describing the effect of temperature on the water conductivity of erythrocyte membranes at subzero temperatures. Cryobiology 1976, 13, 415-429. [CrossRef]

33. Benson, J.D.; Higgins, A.Z.; Desai, K.; Eroglu, A. A toxicity cost function approach to optimal CPA equilibration in tissues. Cryobiology 2018, 80, 144-155. [CrossRef] [PubMed]

34. Ge, M.Y.; Shu, C.; Yang, W.M.; Chua, K.J. Incorporating an immersed boundary method to study thermal effects of vascular systems during tissue cryo-freezing. J. Therm. Biol. 2017, 64, 92-99. [CrossRef]

35. Mochnacki, B.; Majchrzak, E. Numerical model of thermal interactions between cylindrical cryoprobe and biological tissue using the dual-phase lag equation. Int. J. Heat Mass Transf. 2017, 108, 1-10. [CrossRef]

36. Liu, Z.; Wan, R.; Muldrew, K.; Sawchuk, S.; Rewcastle, J. A level set variational formulation for coupled phase change/mass transfer problems: Application to freezing of biological systems. Finite Elem. Anal. Des. 2004, 40, 1641-1663. [CrossRef]

37. Kundu, P.; Sukumar, S.; Kar, S.P. Numerical modeling for freezing and cryogenic preservation for viability of biological tissue. Mater. Today Proc. 2018, 5, 18823-18832. [CrossRef]

38. Mochnacki, B.; Piasecka-Belkhayat, A. Numerical modeling of skin tissue heating using the interval finite difference method. MCB Mol. Cell. Biomech. 2013, 10, 233-244. [CrossRef]

39. Piasecka-Belkhayat, A. Interval boundary element method for $2 \mathrm{D}$ transient diffusion problem using the directed interval arithmetic. Eng. Anal. Bound. Elem. 2011, 35, 259-263. [CrossRef] 
40. Liu, W.; Zhao, G.; Shu, Z.; Wang, T.; Zhu, K.; Gao, D. High-precision approach based on microfluidic perfusion chamber for quantitative analysis of biophysical properties of cell membrane. Int. J. Heat Mass Transf. 2015, 86, 869-879. [CrossRef]

41. Skorupa, A.; Piasecka-Belkhayat, A. Numerical Modeling of Heat and Mass Transfer during Cryopreservation Using Interval Analysis. Appl. Sci. 2021, 11, 302. [CrossRef]

42. Wang, J.; Hou, T. Application of molecular dynamics simulations in molecular property prediction II: Diffusion coefficient. J. Comput. Chem. 2011, 32, 3505-3519. [CrossRef] [PubMed]

43. Mochnacki, B.; Suchy, J. Numerical Methods in Computations of Foundry Processes; Polish Scientific Publishers PWN: Cracow, Poland, 1993.

44. Majchrzak, E.; Mochnacki, B. Numerical Methods. Theoretical Base, Practical Aspects, Algorithms; Publishing House of Silesian University of Technology: Gliwice, Poland, 2004.

45. Schulze, B.M.; Watkins, D.L.; Zhang, J.; Ghiviriga, I.; Castellano, R.K. Estimating the shape and size of supramolecular assemblies by variable temperature diffusion ordered spectroscopy. Org. Biomol. Chem. Suppl. Mater. 2014, 12, S1-S27. [CrossRef] [PubMed] 